\title{
In vitro immunoglobulin synthesis by human intestinal lamina propria lymphocytes
}

\author{
P A DREW, J T LA BROOY, AND D J C SHEARMAN \\ From the Department of Medicine, University of Adelaide, Adelaide, South Australia
}

SUMmARY The concentration of IgG and IgA was measured in the supernatants of peripheral blood mononuclear cells and of cells harvested from the intestinal lamina propria, which were cultured in vitro in the presence or absence of mitogens. The lamina propria mononuclear cells were harvested by collagenase digestion of macroscopically normal mucosa from 10 fresh surgical resections for carcinoma. Secretion of $\operatorname{IgA}$ in cultures of unstimulated lamina propria mononuclear cells greatly exceeded that of IgG. The addition of pokeweed mitogen increased Ig secretion by cultures of peripheral blood mononuclear cells but decreased Ig secretion by lamina propria mononuclear cells. The addition of concanavalin A suppressed Ig synthesis by pokeweed mitogen stimulated cells more in cultures of peripheral blood mononuclear cells than in lamina propria mononuclear cells. Cycloheximide inhibited Ig secretion by more than $90 \%$ in cultures of peripheral blood mononuclear cells, but there was less inhibition in cultures of lamina propria mononuclear cells. In the four unstimulated cultures of lamina propria mononuclear cells examined, over $75 \%$ of the Ig was secreted in the first three to four days of culture. The results indicate that lamina propria mononuclear cells are refractory to the inductive and suppressive signals of mitogens, and represent an activated cell population which is committed to Ig secretion before being cultured.

The predominance of secretory $\operatorname{IgA}$ and of $\operatorname{IgA}$ secreting plasma cells in the gastrointestinal tract, compared with systemic sites - for example, blood, marrow, and spleen - where IgG and IgG producing cells predominate, emphasises the specialised nature of the mucosal component of the immune system. This is also reflected in the antibody response after antigen stimulation at secretory surfaces; protein antigen given parenterally leads to a systemic IgM and IgG response, with little IgA production, whereas given orally it stimulates mainly a local secretory IgA response. ${ }^{1}$

Experiments in mice, in which immunoglobulin synthesis in vitro by spleen or Peyer's patch cells was measured, have suggested an explanation for the difference in the class of Ig produced after antigenic stimulation in the intestine. ${ }^{2}$ Lipopolysaccharide was used to stimulate immunoglobulin synthesis by B cells and concanavalin A (con A) to stimulate suppressor $\mathrm{T}$ cells which inhibit this immunoglobulin synthesis. The experiments showed that spleen cells stimulated with con A suppressed the synthesis of

Address for correspondence: Professor D J C Shearman. University of Adelaide, Adelaide, South Australia 5000.

Received for publication 26 August 1983
IgA, IgM, and IgG by Peyer's patch or spleen B cells, but Peyer's patch cells stimulated with con A, while suppressing $\operatorname{IgM}$ and $\operatorname{IgG}$, enhanced IgA synthesis by $B$ cells. The suppressor cells were shown to be $T$ cells. It was suggested that this difference in suppression by $\mathrm{T}$ cells from the two sites was due to differences in the distribution of subpopulations of immunoglobulin class specific suppressor cells: the spleen having suppressor cells for all three immunoglobulin classes, the Peyer's patch having suppressor cells mainly for IgM and IgG. It was further suggested that this lack of IgA class specific suppressor cells occurs both in the Peyer's patch as well as the lamina propria of the intestine and other secretory sites.

The present studies were designed to examine the possibility that the control mechanisms responsible for the local $\operatorname{IgA}$ response after antigen challenge in the human intestine are similar to those applying in the Peyer's patch of the mouse.

\section{Methods}

TISSUES

Specimens of colon or rectum were obtained at 
operation from patients undergoing surgical resection for carcinoma. All tissues were removed from a site as far distant from the tumour as possible and all were macroscopically normal in appearance. The tissue was transported to the laboratory in Hanks medium, gently wiped with sterile gauze to remove most of the adherent mucus and debris and immediately processed. The period of time from the resection to the beginning of processing was generally less than 45 minutes. The tissue may have been ischaemic for longer than this because of surgical devascularisation of the gut before the resection.

ISOLATION OF PERIPHERAL BLOOD MONONUCLEAR CELLS

Peripheral blood from 32 normal volunteers was collected into heparinised tubes. The peripheral blood mononuclear cells were then isolated on a Ficoll-paque gradient ${ }^{3}$ and washed three times before culture. The peripheral blood mononuclear cells preparations contained more than $95 \%$ viable cells, as judged by the exclusion of trypan blue. Preliminary experiments established that peripheral blood mononuclear cells harvested from patients during the course of major surgery behaved identically with respect to in vitro immunoglobulin synthesis compared with those taken immediately before surgery.

\section{ISOLATION OF LAMINA PROPRIA MONONUCLEAR}

CELLS

A method similar to that of Bull and Bookman ${ }^{4}$ was used to prepare the lamina propria mononuclear cells. Up to $5 \times 5 \mathrm{~cm}$ of the mucosa was dissected free of the underlying submucosa and muscularis, cut into small pieces (approximately $3 \times 3 \mathrm{~mm}$ ), and washed extensively with calcium and magnesium free Hanks balanced salt solution. After a 15 minute incubation in $1 \mathrm{mM}$ dithiothreitol at room temperature the tissue was twice incubated at $37^{\circ} \mathrm{C}$ in Hanks balanced salt solution containing $0.75 \mathrm{mM}$ EDTA, each incubation being for 20 minutes and being followed by three washes with Hanks balanced salt solution. During this step the epithelial cells are freed from the tissue and removed in the washes. The tissue was then incubated overnight in culture medium containing $0.05 \mathrm{mg} / \mathrm{ml}$ collagenase (Type 1A, Sigma). The resultant cell suspension was washed three times in Hanks balanced salt solution and then centrifuged over a Ficoll-paque layer, the lamina propria mononuclear cells at the Ficollpaque boundary being retained. The lamina propria mononuclear cells preparations contained between $60 \%$ and $80 \%$ viable cells, as judged by their ability to exclude trypan blue. The immunoglobulin synthesis by peripheral blood mononuclear cells was not altered by their exposure to the same procedures as applied to the sample of lamina propria during harvesting of the lamina propria mononuclear cells. Results of experiments using tissue from 10 different patients are reported in this study.

\section{IMMUNOGLOBULIN SYNTHESIS in vitro}

The cells were cultured at a concentration of $10 \% / \mathrm{ml}$ in culture medium composed of RPMI 1640 supplemented with $10 \% \mathrm{v} / \mathrm{v}$ heat inactivated fetal bovine serum, $2 \mathrm{mM}$ glutamine, $100 \mu \mathrm{g} / \mathrm{ml}$ penicillin, and 100 units/ml streptomycin. Each culture was set up in a microtitre tray in five replicate wells, each containing $200 \mu \mathrm{l}$ of the cell suspension and $25 \mu \mathrm{l}$ of each mitogen. The cultures were kept at $37^{\circ} \mathrm{C}$ in an incubator gassed with a $5 \% \mathrm{CO}_{2}: 95 \%$ air mixture. The culture supernatants were collected and pooled after eight days' incubation and stored at $-20^{\circ} \mathrm{C}$ until the concentrations of $\operatorname{IgG}$ and $\operatorname{IgA}$ were determined by solid phase radioimmunoassay. All the cultures reported in this study were viable at the end of the culture period, as judged by the ability of the cells to exclude trypan blue. To stimulate immunoglobulin synthesis the $T$ cell dependent $B$ cell mitogen pokeweed mitogen (Sigma) was used at a final concentration of $0 \cdot 1 \mu \mathrm{g} / \mathrm{ml}$, and to measure inducible $\mathrm{T}$ cell suppression con $\mathrm{A}$ (Pharmacia) at a final concentration of $5 \mu \mathrm{g} / \mathrm{ml}$ was added to pokeweed mitogen stimulated cultures. In preliminary experiments, these concentrations of pokeweed mitogen and con $A$ were found to provide maximal stimulation to peripheral blood mononuclear cells. Cycloheximide, an antibiotic which inhibits the synthesis of protein in mammalian cells, was added to some cultures at a final concentration of $50 \mu \mathrm{g} / \mathrm{ml}$. This concentration of cycloheximide resulted in maximal inhibition of immunoglobulin synthesis in preliminary experiments. The use of this inhibitor allowed the determination of the concentration of immunoglobulin preformed in the cells added to the cultures, as opposed to that synthesised in the cultures. Initial experiments using peripheral blood mononuclear cells indicated that the standard error of the mean of replicate unstimulated or pokeweed mitogen stimulated cultures was less than $\pm 10 \%$.

\section{STATISTICS}

All results are reported as the median of the group, with the $95 \%$ confidence limits of the median in parentheses. The data were evaluated using the Wilcoxon's rank sum test, with differences being considered significant when $\mathrm{p}<0 \cdot 05$. 


\section{Results}

IMMUNOGLOBULIN SYNTHESIS BY UNSTIMULATED PERIPHERAL BLOOD MONONUCLEAR CELLS AND LAMINA PROPRIA MONONUCLEAR CELLS

The concentration of $\operatorname{IgG}$ and $\operatorname{IgA}$ in the culture supernatants of unstimulated cells is shown in Fig. 1. The concentration of immunoglobulin was much higher in cultures of lamina propria mononuclear cells than peripheral blood mononuclear cells, with the majority of this immunoglobulin being IgA. In cultures of peripheral blood mononuclear cells there was no significant difference between the concentration of IgG and IgA ( $p>0.05)$, but the concentration of IgA was significantly greater than IgG in the cultures of lamina propria mononuclear cells $(p<0.0001)$. The secretion of IgG by unstimulated lamina propria mononuclear cells, 130 (23-200) $\mu \mathrm{g} / \mathrm{ml}$ (median, $95 \%$ confidence limits of the median), was not different from that of the peripheral blood mononuclear cells, 100 (68-135) $\mu \mathrm{g} / \mathrm{ml}(\mathrm{p}>0.05)$. The secretion of $\operatorname{IgA}$ by lamina propria mononuclear cells, $700(330-1520) \mu \mathrm{g} / \mathrm{ml}$, however, was significantly greater than that by peripheral blood mononuclear cells, 148 (78-215) $\mu \mathrm{g} / \mathrm{ml}(\mathrm{p}<0 \cdot 01)$.
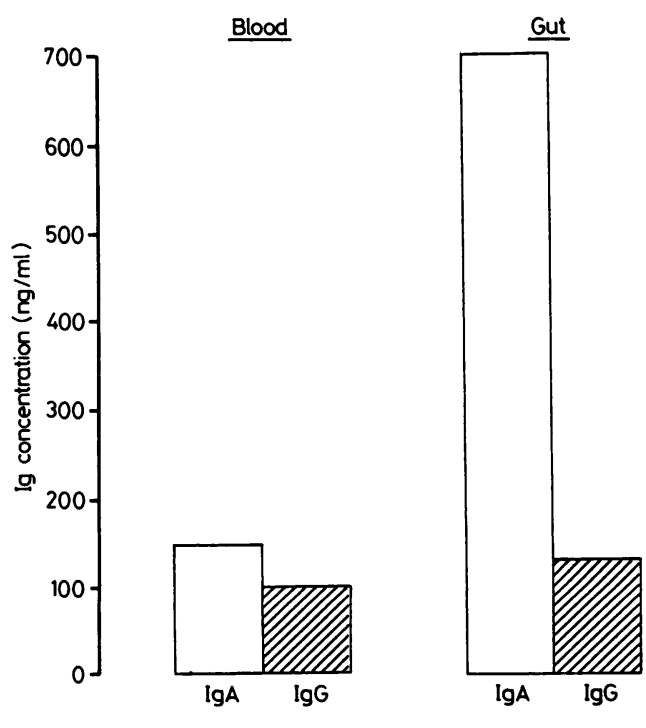

Fig. 1 Concentration of $\operatorname{IgA}$ and $\operatorname{Ig} G$ in supernatant of peripheral blood mononuclear cells and lamina propria mononuclear cells cultured in vitro in absence of mitogens.
IMMUNOGLOBULIN SYNTHESIS BY POKEWEED

MITOGEN STIMULATED PERIPHERAL BLOOD

MONONUCLEAR CELLS AND LAMINA PROPRIA

MONONUCLEAR CELLS

The percentage change in the concentrations of IgG and $\operatorname{IgA}$ in the supernatants of pokeweed mitogen stimulated peripheral blood mononuclear cells and lamina propria mononuclear cells, compared with the unstimulated cells, is shown in Fig. 2. The concentration of $\operatorname{IgG}$ and $\operatorname{IgA}$ was increased in the cultures of peripheral blood mononuclear cells by $183 \%(67-327)$ and $4 \%(-17-+61)$ respectively. In contrast with this enhancement found in cultures of peripheral blood mononuclear cells, pokeweed mitogen decreased the concentration of IgG and IgA in the cultures of lamina propria mononuclear cells by $-17 \%(-30-+143)$ and $-19 \%(-55-0)$ respectively.

\section{EFFECT OF CON A ON POKEWEED MITOGEN}

\section{STIMULATED IMMUNOGLOBULIN SYNTHESIS}

The percentage change in the concentration of $\operatorname{IgG}$ and IgA in the supernatants of peripheral blood mononuclear cells and lamina propria mononuclear cells cultured with both pokeweed mitogen and con A, compared with the cells cultured with pokeweed mitogen alone, is shown in Fig. 3. The effect of con A was to reverse any increase in immunoglobulin synthesis due to pokeweed mitogen and to reduce the concentration of immunoglobulin in the culture supernatants to background or less. The change induced by con $A$ in the $\operatorname{IgG}$ and $\operatorname{IgA}$ concentrations in the cultures of peripheral blood mononuclear

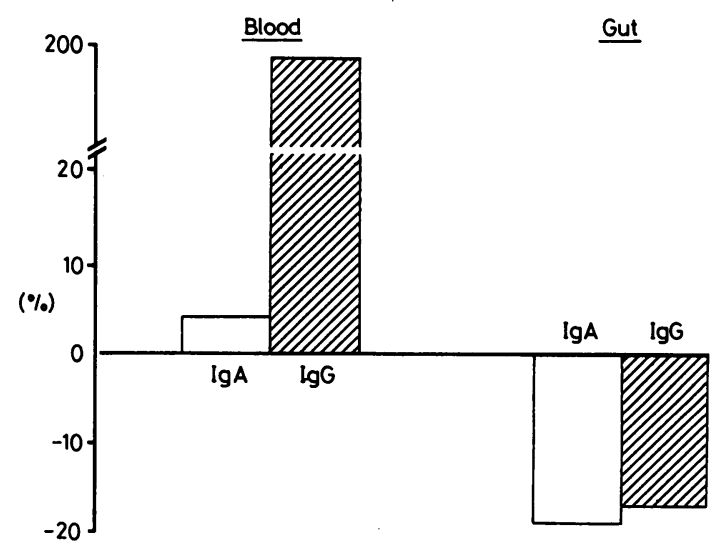

Fig. 2 Percentage change in concentration of $\operatorname{IgA}$ and $\operatorname{IgG}$ in culture supernatant of peripheral blood mononuclear cells and lamina propria mononuclear cells stimulated with pokeweed mitogen, compared with unstimulated cells. 


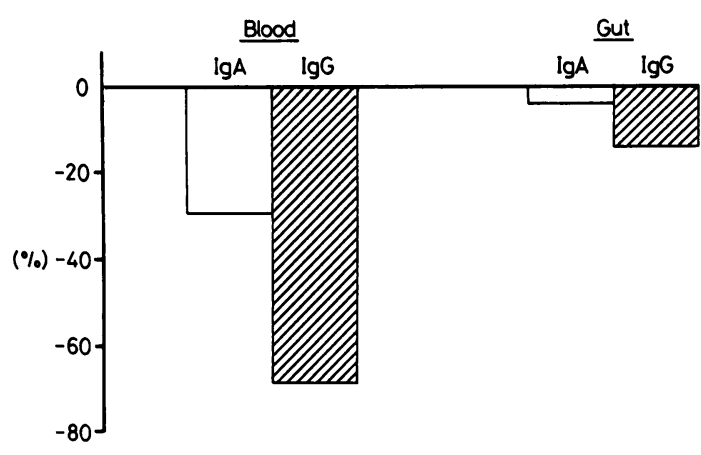

Fig. 3 Percentage change in concentration of $\operatorname{Ig} A$ and $\operatorname{Ig} G$ in culture supernatant of peripheral blood mononuclear cells and lamina propria mononuclear cells stimulated with both pokeweed mitogen and con A, compared with pokeweed mitogen alone.

cells was $-68 \%(-82--51)$ and $-30 \%(-50--18)$ respectively, and $-14 \%(-71-+10)$ and $-3 \%$ $(-45-+69)$ in cultures of lamina propria mononuclear cells. Compared with the cultures of lamina propria mononuclear cells, con A induced a significantly greater suppression in peripheral blood mononuclear cells of IgG $(p<0.0001)$ and $\operatorname{IgA}$ $(p<0.01)$ synthesis. In comparing the effect of con A on cultures of cells from the same site - that is, either intestine or blood - no difference between the suppression of $\operatorname{IgG}$ and of $\operatorname{IgA}$ was apparent.

\section{EFFECT OF THE ADDITION OF CYCLOHEXIMIDE TO CULTURES OF LAMINA PROPRIA MONONUCLEAR CELLS}

Initial experiments indicated that the addition of 50 $\mu \mathrm{g} / \mathrm{ml}$ of cycloheximide to cultures of pokeweed mitogen stimulated peripheral blood mononuclear cells inhibited the secretion of IgG and IgA by more than $90 \%$. The results in Figure 4 show that, in those culture supernatants in which it was measured, cycloheximide inhibited both IgG (eight cultures) and $\operatorname{IgA}$ (six cultures) secretion by lamina propria mononuclear cells significantly less than in the peripheral blood mononuclear cells $(p<0.001)$. Most lamina propria mononuclear cell preparations examined continued to secrete immunoglobulin in the presence of cycloheximide, although the amount varied considerably between different cell preparations.

TIME COURSE OF IMMUNOGLOBULIN SYNTHESIS BY LAMINA PROPRIA MONONUCLEĄR CELLS

For each of four samples of lamina propria mononuclear cells, pokeweed mitogen stimulated cultures were set up in duplicate. One of the duplicates was

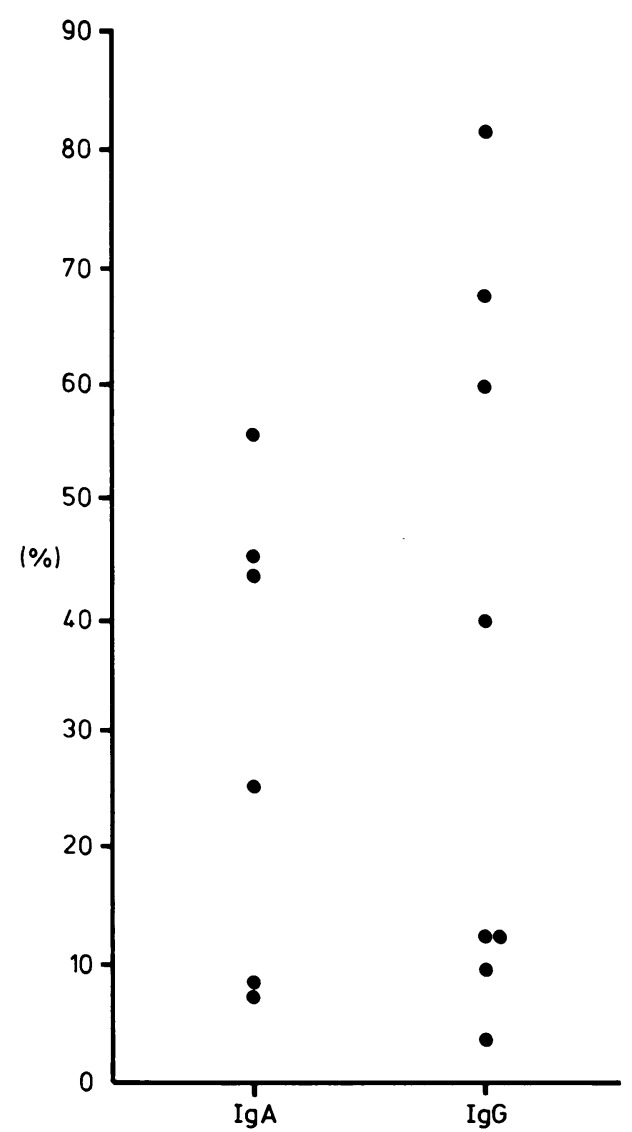

Fig. 4 Effect of addition of cycloheximide on $\operatorname{Ig} A$ and $\operatorname{Ig} G$ concentration in culture supernatant of lamina propria mononuclear cells stimulated with pokeweed mitogen. Results are expressed as percentage of Ig in supernatant when cycloheximide was, compared with when it was not, added to cultures.

sampled after four days of culture, the other after eight days, and each sample was assayed for immunoglobulin. The results in Figure 5 show the changes between the fourth and the eighth day of culture in the concentrations of $\operatorname{IgG}$ and $\operatorname{IgA}$ for each of these preparations. It can be seen that the majority of the immunoglobulin secretion occurred in the first four days of culture.

\section{Discussion}

The results indicate that viable lymphoid cells can be harvested from the intestinal lamina propria and that these cells, cultured in vitro, synthesise and secrete $\operatorname{IgG}$ and $\operatorname{IgA}$ into the supernatant. There are 


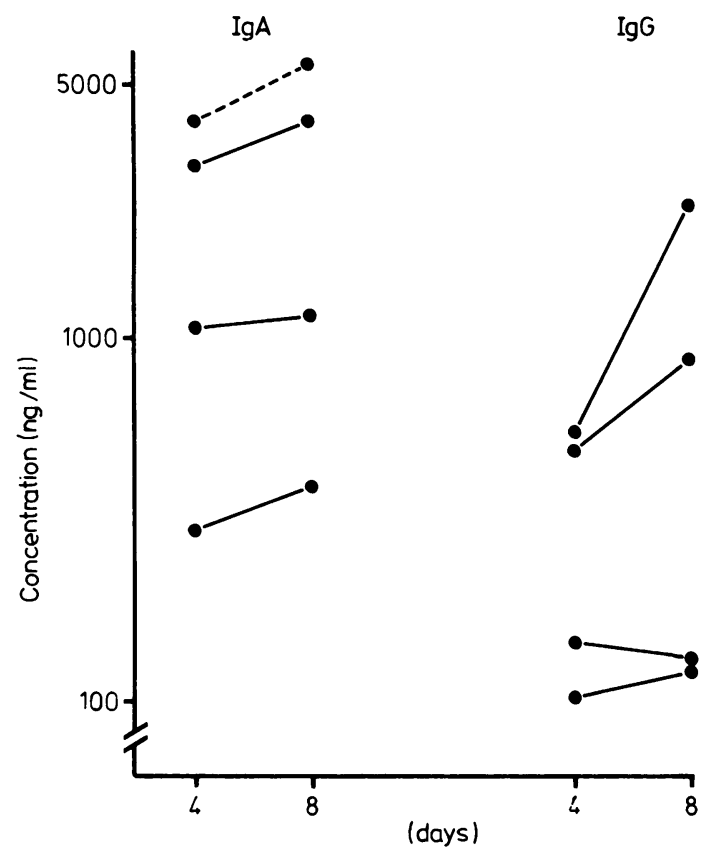

Fig. 5 Concentration of $\lg G$ and $\lg A$ in supernatant of pokeweed mitogen stimulated lamina propria mononuclear cells cultured for four and eight days.

significant differences, however, between peripheral blood mononuclear cells and lamina propria mononuclear cells in the pattern of this synthesis and secretion. Firstly, the spontaneous secretion of immunoglobulin is significantly higher for lamina propria mononuclear cells, with most of it being IgA. Secondly, the mitogens pokeweed mitogen and con A have relatively little effect on immunoglobulin secretion by lamina propria mononuclear cells. While pokeweed mitogen induces a significant increase in immunoglobulin secretion by peripheral blood mononuclear cells, and con A suppresses this, both mitogens have a small inhibitory influence on secretion by the lamina propria mononuclear cells.

These differences suggest that the lymphocytes which are recovered from the lamina propria by our techniques are an activated population and contain very few unstimulated $B$ cells. Cycloheximide, an inhibitor of protein synthesis, reduces by over $90 \%$ the pokeweed mitogen induced secretion of immunoglobulin by peripheral blood mononuclear cells, but has much less effect on the secretion by lamina propria mononuclear cells. It has been shown that peripheral blood mononuclear cells, stimulated in vitro with pokeweed mitogen, do not begin to secrete newly synthesised immunoglobulin into the supernatant until around the fourth day of culture, ${ }^{56}$ whereas the results reported here indicate that lamina propria mononuclear cells secrete the majority of their immunoglobulin before this time. This is consistent with the cells being triggered for immunoglobulin synthesis in vivo rather than in vitro. The fact that pokeweed mitogen does not increase immunoglobulin secretion by the lamina propria mononuclear cells also suggests that there are very few unstimulated B cells present.

The finding that the culture supernatants of unstimulated lamina propria mononuclear cells contain a relatively high concentration of immunoglobulin, particularly $\operatorname{IgA}$, is not new. Bull and Bookman reported that lamina propria mononuclear cells, cultured for 48 hours in vitro, incorporated 35 times as much radioactive amino acid into protein precipitable with anti-immunoglobulin reagents as peripheral blood mononuclear cells. ${ }^{4}$ Fiocchi et al measured five times the IgM in supernatants of unstimulated cultures of lamina propria mononuclear cells after seven to eight days' culture, compared with similar cultures of peripheral blood mononuclear cells. ${ }^{7}$ Similarly, MacDermott et al measured moderately increased spontaneous secretion of $\operatorname{IgG}$ and $\operatorname{IgM}$ and markedly increased spontaneous secretion of $\operatorname{IgA}$ in 12 day cultures of lamina propria mononuclear cells. $^{89}$ In our cultures, which were incubated for eight days, the secretion of IgG by lamina propria mononuclear cells was not increased compared with peripheral blood mononuclear cells, but the secretion of $\operatorname{IgA}$ was increased, although not as markedly as reported by MacDermott et al. These differences, which are of degree only, may reflect the differences in the culture period used, or slight differences in the culture conditions - for example, the batch of fetal bovine serum used to supplement the cultures.

The observation that B cells in the lamina propria mononuclear cells are activated and not greatly influenced by the inductive or suppressive signals resulting from mitogen stimulation is important. MacDermott $e t$ al observed that pokeweed mitogen stimulation of lamina propria mononuclear cells resulted in little or no increase in immunoglobulin synthesis, and occasionally was suppressive. In the experiments reported here pokeweed mitogen induced a larger and more consistent suppression of both IgG and IgA synthesis. As well, con A, which induces suppressor $\mathrm{T}$ lymphocytes, ${ }^{10}$ suppressed immunoglobulin synthesis significantly more when added to cultures of pokeweed mitogen stimulated peripheral blood mononuclear cells, compared with pokeweed mitogen stimulated lamina propria mononuclear cells. The lack of effect of con A on immunoglobulin synthesis by lamina propria mono- 
nuclear cells is further evidence that these lymphoid cells are activated in vivo, because suppressor $\mathrm{T}$ lymphocytes generated by con A act only during the early events of priming. ${ }^{11}$

The suppression of immunoglobulin synthesis by pokeweed mitogen, reported here for cultures of lamina propria mononuclear cells, may also occur in cultures of peripheral blood mononuclear cells. Most commonly this occurs with the cells harvested from patients with those diseases in which the peripheral blood mononuclear cells secrete increased amounts of immunoglobulin in culture. Thus pokeweed mitogen has been reported either to have no effect on, or suppress, IgG and $\operatorname{IgA}$ synthesis by peripheral blood mononuclear cells harvested from patients with Henoch Schonlein purpura and systemic lupus erythematosus, ${ }^{12}{ }^{13}$ and to suppress IgA synthesis from IgA nephropathy ${ }^{13}$ and IgG synthesis from alcoholic cirrhosis. ${ }^{14}$

It is not surprising that $B$ cells harvested from the lamina propria appear to be more activated in culture than those from the peripheral blood. Although the gut acts as a physical barrier to separate the enormous potential antigen load in its lumen from the tissue of the body, this barrier is not complete. Macromolecules and micro-organisms are capable of crossing the intestine and entering into the portal or systemic circulation, either via the ordinary glandular epithelium which covers the villi or the specialised epithelium which covers the Peyer's patches. ${ }^{15} 16$ These antigens then stimulate the $B$ cells to secrete immunoglobulin. In germ free adult mice the density of $\operatorname{IgA}$ plasma cells in different parts of the intestine is on average only $10 \%$ of that found in conventional mice, suggesting a causal relationship between the presence in the intestinal lumen of living microbial flora and the development of cells synthesising $\operatorname{IgA}$ in the gut mucosa. ${ }^{17}$ In man a substantial number of the plaque forming cells recovered from the intestinal lamina propria synthesise antibody specific for common faecal coliforms, particularly in the distal colon, where coliform bacteria are found in the greatest numbers. ${ }^{18}$ Direct evidence for the ability of antigen in the lumen of the gut to influence the activity of lymphoid cells in the lamina propria comes from the work of Husband and Gowans. ${ }^{19}$ They showed that antibody producing cells, primed in the Peyer's patches, accumulated, divided and persisted in the lamina propria of the small intestine only when the specific antigen was present in the gut lumen.

A major difference between the experiments described in this paper, and those referred to concerning the control of $\operatorname{IgG}$ and $\operatorname{IgA}$ synthesis in mice, is the use of cells from the lamina propria rather than the Peyer's patch. This was necessary because lamina propria mononuclear cells are readily available in the human, whereas Peyer's patch cells are not. It is clear from early studies in rabbits and rodents that priming for an antibody response to orally administered antigen occurs in the Peyer's patch. ${ }^{19} 20$ Antigen challenge in the human colon, ${ }^{21}$ or the rabbit ileum from which Peyer's patches have been removed, however ${ }^{22}$ also results in a local secretory $\operatorname{IgA}$ response; it is therefore reasonable to expect that similar mechanisms controlling the class of immunoglobulin exist in the intestinal lamina propria.

We have found that $B$ cells from the intestinal lamina propria are activated when harvested and are not responsive to the inductive or suppressive signals of the mitogens used. To determine whether the $T$ cells in the human intestinal lamina propria preferentially enhance IgA synthesis, as has been shown for the Peyer's patch T cells in mice, will necessitate the separation of the $T$ cells from the lamina propria mononuclear cells and their coculture with the unstimulated B cells from peripheral blood.

We thank Mrs D Pyle for skilful technical assistance, and the surgeons of the Royal Adelaide Hospital for their cooperation in providing tissue. P A Drew was in receipt of a Research Associateship from the University of Adelaide.

\section{References}

1 Richman LK, Chiller JM, Brown WR, Hanson DG, Vaz NM. Enterically induced immunologic tolerance. I. Induction of suppressor $\mathrm{T}$ lymphocytes by intragastric administration of soluble proteins. $J$ Immunol 1978; 121: 2429-34.

2 Elson CO, Heck JA, Strober W. T-cell regulation of murine IgA synthesis. J Exp Med 1979; 149: 632-43.

3 Boyum A. IV. Isolation of mononuclear cells and granulocytes from human blood. Scand J Clin Lab Invest 1968; 21: suppl 97: 77-89.

4 Bull BM, Bookman MA. Isolation and functional characterization of human intestinal mucosal lymphoid cells. J Clin Invest 1977; 59: 966-74.

5 Choi YS, Good RA. Differentiation of human peripheral blood B lymphocytes. Immunology 1977; 33: 887-94.

6 Munoz J, Pryjma J, Fudenberg HH, Virella G. Immunoglobulin quantitation and enumeration of immunoglobulin-producing cells: comparison of two indexes of B-cell activation. Scand J Immunol 1980; 12: 345-53.

7 Fiocchi MD, Battisto JR, Farmer RG. Gut mucosal 
lymphocytes in inflammatory bowel disease. Isolation and preliminary functional characterization. Dig Dis Sci 1979; 24: 705-17.

8 MacDermott RP, Nash GS, Bertovich MJ, Seiden MV, Bragdon MJ, Beale MG. Alterations of IgM, IgG, and IgA secretion by peripheral blood (PB) and intestinal (INT) mononuclear cells (MNC) in inflammatory bowel disease (IBD). Gastroenterology 1981; 81 (5) Part 2: 1219.

9 MacDermott RP, Nash GS, Bertovich MJ, Seiden MV, Bragdon MJ, Beale MG. Alterations of IgM, IgG, and IgA secretion by peripheral blood and intestinal mononuclear cells from patients with ulcerative colitis and Crohn's disease. Gastroenterology 1981; 81: 84452.

10 Haynes BF, Fauci AS. Activation of human B lymphocytes. III. Concanavalin A-induced generation of suppressor cells of the plaque-forming cell response of normal human B lymphocytes. J Immunol 1977; 118: 2281-7.

11 Dutton RW. Suppressor T cells. Transplant Rev 1975; 26: 39-55.

12 Beale MG, Nash GS, Bertovich MJ, MacDermott RP. Similar disturbances in B cell activity and regulatory $T$ cell function in Henoch-Schonlein purpura and systemic lupus erythematosus. J Immunol 1982; 128: 486-90.

13 Bannister KM, Drew PA, Clarkson AR, Woodroffe AJ. Immunoregulation in glomerulonephritis, HenochSchonlein purpura and lupus nephritis. Clin Exp
Immunol 1983; 53: 384-90.

14 Holdstock G, Ershler WB, Krawitt EL. Demonstration of non-specific B-cell stimulation in patients with cirrhosis. Gut 1982; 23: 724-8.

15 Walker WA, Isselbacher KJ. Uptake and transport of macromolecules by the intestine: possible role in clinical disorders. Gastroenterology 1974; 67: 531-50.

16 Editorial. Antigen absorption by the gut. Lancet 1978; 2: 715-7.

17 Crabbe PA, Bazin H, Eyssen H, Heremans JF. The normal microbial flora as a major stimulus for proliferation of plasma cells synthesizing $\mathrm{IgA}$ in the gut. Int Arch Allergy 1968; 34: 362-75.

18 Heddle RJ, LaBrooy JT, Shearman DJC. Escherichia coli antibody-secreting cells in the human intestine. Clin Exp Immunol 1982; 48: 469-76.

19 Husband AJ, Gowans JL. The origin and antigendependent distribution of $\operatorname{IgA}$ containing cells in the intestine. J Exp Med 1978; 148: 1146-60.

20 Craig SW, Cebra JJ. Peyer's patches, an enriched source of precursors for $\mathrm{IgA}$-producing immunocytes in the rabbit. J Exp Med 1971; 134: 188-200.

21 Ogra PL, Karzon, DT. Distribution of poliovirus antibody in serum, nasopharynx and alimentary tract following segmental immunization of lower alimentary tract with poliovaccine. J Immunol 1969; 102: 1423-30.

22 Hamilton SR, Keren DF, Yardley JH, Brown G. No impairment of local intestinal response to keyhole limpet haemocyanin in the absence of Peyer's patches. Immunology 1981; 42: 431-7. 